\title{
GAS EXCHANGE AND PHOTOCHEMICAL EFFICIENCY IN LIMA BEAN GENOTYPES GROWN IN COMPACTED SOILS ${ }^{1}$
}

\author{
RENATO FRANCISCO DA SILVA SOUZA ${ }^{2 *}$, DJAIL SANTOS ${ }^{3}$, WALTER ESFRAIN PEREIRA ${ }^{4}$, FABRÍCIO LOPES \\ DE MACEDO ${ }^{5}$, JHONY VENDRUSCOLO ${ }^{2}$
}

\begin{abstract}
The effects of soil compaction on crop growth and productivity have been well studied in recent years, however, studies on the physiological responses of crops to compaction are scarce. The objective of this study was to evaluate the effect of soil compaction on gas exchange, and photochemical efficiency of lima bean (Phaseolus lunatus L.) genotypes of different growth habits. The experimental design was a randomized block in a $3 \times 4$ factorial arrangement, with three lima bean genotypes (Branca-Pequena, Orelha-de-Vó and Roxinha) and four compaction levels (soil densities of 1.1, 1.3, 1.5 and $1.7 \mathrm{~g} \mathrm{~cm}^{-3}$ ), with four replications. The following variables were evaluated at 38 days after sowing: photosynthetic rate $(A)$, leaf transpiration $(E)$, stomatal conductance $\left(\mathrm{g}_{\mathrm{s}}\right)$, internal $\mathrm{CO}_{2}$ concentration $(\mathrm{Ci})$, instantaneous water use efficiency (WUE), intrinsic water use efficiency (iWUE), instantaneous carboxylation efficiency (iCE) and photochemical efficiency ( $F o, F m, F v$ and $F v / F m$ ). The data were subjected to analysis of variance at $5 \%$ probability by the $\mathrm{F}$ test. The genotypes showed a reduction in the photosynthetic rate with increasing soil compaction. The soil compaction affected the photochemical efficiency of the genotype Orelha-de-Vó, with the $F m$ and $F v$ fitting to the linear model, and the $F v / F m$ fitting to the quadratic model. The genotype Orelha-de-Vó had the highest rate of $E$ and $\mathrm{g}_{\mathrm{s}}$ at the soil densities of 1.24 and $1.29 \mathrm{~g} \mathrm{~cm}^{-3}$, respectively. Regarding the photosynthetic rate, the genotype Roxinha is more efficient than Branca-Pequena at the soil density of $1.7 \mathrm{~g} \mathrm{~cm}^{-3}$.
\end{abstract}

Keywords: Phaseolus lunatus L.. Physical impediment. Photosynthetic rate.

\section{TROCAS GASOSAS E EFICIÊNCIA FOTOQUÍMICA DE GENÓTIPOS DE FAVA CULTIVADOS EM SOLO COMPACTADO}

RESUMO - Os efeitos da compactação do solo no crescimento e produtividade das culturas têm sido muito estudados nos últimos anos, porém, as respostas fisiológicas das culturas à compactação não têm recebido a devida atenção. Objetivou-se avaliar o efeito da compactação do solo nas trocas gasosas e na eficiência fotoquímica de genótipos de fava (Phaseolus lunatus L.) de diferentes hábitos de crescimento. O delineamento experimental utilizado foi em blocos casualizados no arranjo fatorial $3 \times 4$, sendo três genótipos de fava (Branca pequena, Orelha de vó e Roxinha) e quatro níveis de compactação (densidades de solo de 1,$1 ; 1,3 ; 1,5$ e $1,7 \mathrm{~g} \mathrm{~cm}^{-3}$ ), com quatro repetições. Aos 38 dias após a semeadura, analisaram-se as seguintes variáveis: taxa fotossintética $(A)$, transpiração foliar $(E)$, condutância estomática $\left(\mathrm{g}_{\mathrm{s}}\right)$, concentração interna de $\mathrm{CO}_{2}(\mathrm{Ci})$, eficiência instantânea no uso da água (EUA), eficiência intrínseca no uso da água (EIUA), eficiência instantânea de carboxilação (EiC) e eficiência fotoquímica $(F o, F m, F v$ e $F v / F m)$. Os dados foram submetidos à análise de variância a $5 \%$ de probabilidade pelo teste F. Os genótipos apresentaram redução na taxa fotossintética com aumento da compactação do solo. Houve efeito da compactação do solo na eficiência fotoquímica apenas para o genótipo 'Orelha de vó', com ajustes do modelo linear para $F m$ e $F v$, e quadrático para relação $F v / F m$. O genótipo 'Orelha de vó' atingiu a maior taxa de $E$ e gs nas densidades de solo 1,24 e $1,29 \mathrm{~g} \mathrm{~cm}^{-3}$, respectivamente. Em relação a taxa fotossintética, o genótipo 'Roxinha' é mais eficiente que o genótipo 'Branca pequena' na densidade do solo de $1,7 \mathrm{~g} \mathrm{~cm}^{-3}$.

Palavras-chave: Phaseolus lunatus L.. Impedimento físico. Taxa fotossintética.

\footnotetext{
*Corresponding author

${ }^{1}$ Received for publication in $12 / 22 / 2016$; accepted in $06 / 26 / 2017$.

Paper extracted from the master's thesis of the first author.

${ }^{2}$ Universidade Federal da Paraíba, Areia, PB, Brazil; renatofssouza@live.com, jhoven2@hotmail.com.

${ }^{3}$ Departament Soils and Rural Engineering, Universidade Federal da Paraíba, Areia, PB, Brazil; santosdj@cca.ufpb.br.

${ }^{4}$ Departament of Fundamental and Social Science, Universidade Federal da Paraíba, Areia, PB, Brazil; walterufpb@yahoo.com.br.

${ }^{5}$ Centre for The Research and Technology of Agro-Environmental and Biological, Universidade de Trás-os-Montes e Alto Douro, Vila Real, VR, Portugal; fabriciolmacedo@hotmail.com.
} 


\section{INTRODUCTION}

Soil compaction limits the volume of soil explored by the roots, reducing the root system growth, and consequently, the development and productivity of several crops (MOURA et al., 2008; GUBIANI; REICHERT; REINERT, 2014; VALADÃO et al., 2015). Information on soil compaction is essential for planning soil management; however, few studies focus on the effects of compaction on physiological aspects of the plant, making it difficult to understand the performance of the cultures in this stress condition (GRZESIAK et al., 2013).

Soil compaction changes the soil structure and, consequently, decrease its total porosity, macroporosity, and water and oxygen availability (NAWAZ; BOURRIÉ; TROLARD, 2013; GRZESIAK et al., 2016). This increases soil resistance to penetration and limits the root system growth. Therefore, plants grown in compacted soils have their physiological functioning altered, with reductions in their photosynthetic rate due to stomatal and non-stomatal limitations; reductions in water and nutrient absorption; changes in the production of growth hormones, especially abscisic acid, and ethylene; and decreases of chlorophyll synthesis (KOZLOWSKI, 1999).

The soil compaction level can be quantified by the soil density, which increases the soil resistance to penetration (SUZUKI et al., 2007; HERNANDEZ-RAMIREZ et al., 2014; KUNCORO et al., 2014). Soil compaction levels between 2.0 and 2.5 $\mathrm{MPa}$ were reported as the critical limits of resistance to penetration for most vegetables (SILVEIRA et al., 2010). In soil with sandy loam texture, with densities varying from 1.0 to $1.6 \mathrm{~g} \mathrm{~cm}^{-3}$, the soil resistance to penetration can vary from 0.1 to 6.1 MPa, respectively (STONE; GUIMARÃES; MOREIRA, 2002). In common beans, the soil resistance to penetration of $1.7 \mathrm{MPa}$ is critical, compromising the maximum grain yield (LIMA et al., 2010).

Lima bean (Phaseolus lunatus L.) can be grown both for grain production and for use as a green manure (PEGADO et al., 2008) and has a broader adaptation capacity than common bean. However, few studies evaluated this crop under stress conditions, and provided information about its agronomic potential in the Semiarid region of Brazil. The objective of this study was to evaluate the effect of soil compaction on gas exchange, and photochemical efficiency of lima bean (Phaseolus lunatus L.) genotypes of different growth habits.

\section{MATERIAL AND METHODS}

The experiment was conducted in a protected environment in the Agricultural Sciences Center (CCA) of the Federal University of Paraíba (UFPB), in Areia in the state of Paraiba (PB), Brazil, from December 2015 to January 2016. The region's climate is classified as hot and humid, and has an average annual precipitation of $1395 \mathrm{~mm}$ (CCA/ UFPB Meteorological Station, INMET-OMM: 82696, 1965-2014). During the experimental period, the maximum, average, and minimum air temperature inside the protected environment were assessed daily by minimum and maximum thermometers (Figure 1).

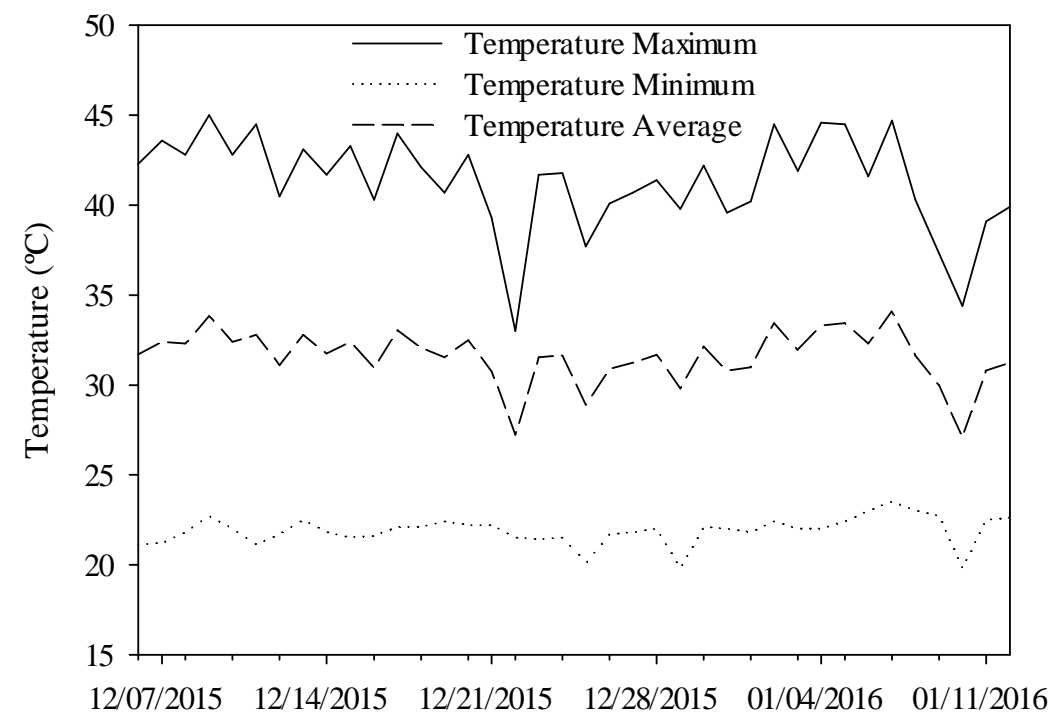

Experimental period

Figure 1. Maximum, average, and minimum air temperature $\left({ }^{\circ} \mathrm{C}\right.$ day $\left.{ }^{-1}\right)$, measured inside the protected environment during the experimental period. 
The soil used in the experiment was collected in the layer $0.00-0.20 \mathrm{~m}$ of an area of Ultisol (abruptic distrophic Red-Yellow Argissolo - SiBCS) in the CCA/UFPB Campus, and sent to the laboratory for chemical, fertility, and granulometry analysis, according to EMBRAPA (2011) (Table 1).

Table 1. Chemical characteristics, fertility, and granulometry of the layer $0.00-0.20 \mathrm{~m}$ of an Ultisol (abruptic distrophic Red-Yellow Argissolo - SiBCS).

\begin{tabular}{|c|c|c|c|c|c|c|c|c|c|c|c|c|c|}
\hline \multicolumn{11}{|c|}{ Attribute } & \multicolumn{3}{|c|}{ Granulometry } \\
\hline$\overline{\mathrm{pH}^{1}}$ & $\begin{array}{c}\mathrm{P} \\
\mathrm{mg} \mathrm{dm}^{-3}\end{array}$ & $\mathrm{~K}^{+}$ & $\mathrm{Na}^{+}$ & $\begin{array}{l}\mathrm{Ca}^{2+} \\
--\mathrm{c}\end{array}$ & $\begin{array}{l}\mathrm{Mg}^{2+} \\
\mathrm{ol}_{\mathrm{c}} \mathrm{dm}\end{array}$ & $\mathrm{Al}^{3+}$ & $\mathrm{H}+\mathrm{Al}$ & $\mathrm{m}$ & $\mathrm{V}$ & $\begin{array}{c}\mathrm{OM} \\
\mathrm{g} \mathrm{kg}^{-1}\end{array}$ & Sand & $\begin{array}{r}\text { Silt } \\
-\mathrm{g} \mathrm{kg}^{-}\end{array}$ & Clay \\
\hline 5.9 & 35 & 0.85 & 0.11 & 2.9 & 1.8 & 0.0 & 4.2 & 0.0 & 58 & 52.22 & 686 & 121 & 193 \\
\hline
\end{tabular}

${ }^{1} \mathrm{H}_{2} \mathrm{O}(1: 2.5) ; \mathrm{m}=\mathrm{Al}^{3+}$ saturation; $\mathrm{V}=$ base saturation; $\mathrm{OM}=$ Organic matter.

Seeds of the genotypes Branca-Pequena, Orelha-de-Vó and Roxinha (Table 2) were obtained from small producers of the micro-regions of Campina Grande, PB, and Curimataú Paraibano, PB.

The seeds were subjected to surface disinfestation with ethanol $\left(\mathrm{C}_{2} \mathrm{H}_{6} \mathrm{O}\right)$ at $70 \%$ for 30 seconds and sodium hypochlorite $(\mathrm{NaClO})$ at $1 \%$ for 1 minute. These seeds were then germinated in germ test papers in BOD for 48 hours, with a temperature of $27 \pm 2^{\circ} \mathrm{C}$ under photoperiod of
12 hours until radicle emission. Then, they were seeded in PVC columns with different compaction levels. The moisture of the columns was maintained between 70 and $80 \%$ field capacity, with irrigation in the surface layer until the $19^{\text {th }}$ day after sowing (DAS), and by capillarity from the $20^{\text {th }}$ to $38^{\text {th }}$ DAS, to stimulate the rupture of the compacted soil layer by the root system (SILVA; MAIA; BIANCHINI, 2006).

Table 2. Characteristics of lima bean (Phaseolus lunatus L.) genotypes.

\begin{tabular}{|c|c|c|c|c|}
\hline \multirow{2}{*}{ Genotypes } & \multicolumn{2}{|c|}{ Growth habit } & \multirow{2}{*}{$\begin{array}{c}\text { Germination } \\
(\%)\end{array}$} & \multirow{2}{*}{$\begin{array}{c}\text { 100-Grain weight } \\
(\mathrm{g})\end{array}$} \\
\hline & Growth & Type & & \\
\hline Branca-Pequena & Determinate & I & 98 & 29.3 \\
\hline Orelha-de-Vó & Indeterminate & III & 88 & 82.7 \\
\hline Roxinha & Indeterminate & IV & 92 & 33.4 \\
\hline
\end{tabular}

The experimental unit consisted of a column formed with three $100 \mathrm{~mm}$ diameter PVC rings. The lower ring was $12.0 \mathrm{~cm}$ high and had a $1 \mathrm{~mm}$ screen covering the bottom; it was filled with soil presenting density of $1.1 \mathrm{~g} \mathrm{~cm}^{-3}$. The intermediate ring was $3.5 \mathrm{~cm}$ high and was filled with soil presenting densities of $1.1 \mathrm{~g} \mathrm{~cm}^{-3}$ (control), and 1.3 , 1.5 or $1.7 \mathrm{~g} \mathrm{~cm}^{-3}$. The soil densities were obtained by successive strikes with an iron mass of $6 \mathrm{~kg}$ in the soil with moisture close to field capacity. The top ring was $12.0 \mathrm{~cm}$ high and was filled with soil at the density of $1.1 \mathrm{~g} \mathrm{~cm}^{-3}$ up to $10.0 \mathrm{~cm}$, leaving $2.0 \mathrm{~cm}$ of edge for irrigation. A $2 \mathrm{~cm}$ wide strip was placed around the upper edge of the intermediate ring to prevent root penetration between the PVC columns.

Planting fertilization was carried out according to the soil analysis, and consisted in applying a solution of $150 \mathrm{~g} \mathrm{~cm}^{-3}$ of $\mathrm{N}$ (urea), $200 \mathrm{~g}$ $\mathrm{cm}^{-3} \mathrm{P}_{2} \mathrm{O}_{5}$ (simple superphosphate), and $150 \mathrm{~g} \mathrm{~cm}^{-3}$ of $\mathrm{K}_{2} \mathrm{O}$ (potassium chloride), representing 15, 20 and $15 \mathrm{~kg} \mathrm{ha}^{-1}$ of $\mathrm{N}, \mathrm{P}_{2} \mathrm{O}_{5}$ and $\mathrm{K}_{2} \mathrm{O}$, respectively.

The experimental design was a randomized block with $3 \times 4$ factorial arrangement, with three lima bean genotypes (Branca-Pequena, Orelha-de-Vó and Roxinha) and four compaction levels $\left(1.1,1.3,1.5\right.$ and $\left.1.7 \mathrm{~g} \mathrm{~cm}^{-3}\right)$, with four replications.

The following variables were evaluated: photosynthetic rate $(A)$, leaf transpiration $(E)$, stomatal conductance $\left(\mathrm{g}_{\mathrm{s}}\right)$, internal $\mathrm{CO}_{2}$ concentration (Ci), instantaneous water use efficiency (WUE), intrinsic water use efficiency (iWUE), instantaneous carboxylation efficiency (iCE), initial fluorescence $(F o)$, maximum fluorescence $(F m)$, variable fluorescence $(F v)$ and quantum efficiency of photosystem II $(F v / F m)$.

The gas exchange evaluations were performed at the $38^{\text {th }}$ DAS, by measuring the photosynthetic rate $(A)$, leaf transpiration $(E)$, stomatal conductance $\left(\mathrm{g}_{\mathrm{s}}\right)$, internal $\mathrm{CO}_{2}$ concentration ( $\mathrm{Ci})$ using an infrared gas analyzer (IRGA, ADC System). Readings were performed between 9:00 a.m. and 11:00 a.m. with an external actinic light (Q) of $1200 \mu \mathrm{mol} \mathrm{m} \mathrm{s}^{-2}$, using the third fully expanded leaf from the apex of the main branch.

After the data collection, the instantaneous water use efficiency (WUE) was evaluated by the ratio between photosynthetic and transpiration rate $\left(A E^{-1}\right)$; the intrinsic water use efficiency (iWUE) was evaluated through the ratio between the photosynthetic rate and stomatal conductance $\left(A \mathrm{~g}_{\mathrm{s}}^{-1}\right)$; and the instantaneous carboxylation efficiency (iCE) was evaluated by the relation between the photosynthetic rate and the internal $\mathrm{CO}_{2}$ concentration $\left(A \mathrm{Ci}^{-1}\right)$ (MACHADO et al., 2005; 
SANTOS et al., 2009).

The photochemical efficiency was evaluated using a modulated fluorometer (Plant Efficiency Analyzer PEA II ${ }^{\circledR}$, Hansatech Instruments Co., UK) and the same leaves used for the gas exchange evaluations, which were adapted to the dark for 30 minutes.

The mean data ( $\mathrm{n}=3$ per plot) were analyzed for homogeneity of variance (Levene) and normality (Kolmogorov-Smirnov), and no data transformation was required. Subsequently, these data were subjected to analysis of variance by the F test at 5\% probability, using the software SISVAR (FERREIRA, 2008). Genotypes with significant means were evaluated by the Tukey's test at 5\% probability and soil densities by regression analysis from the $\mathrm{F}$ test at $10 \%$ probability.

\section{RESULTS AND DISCUSSION}

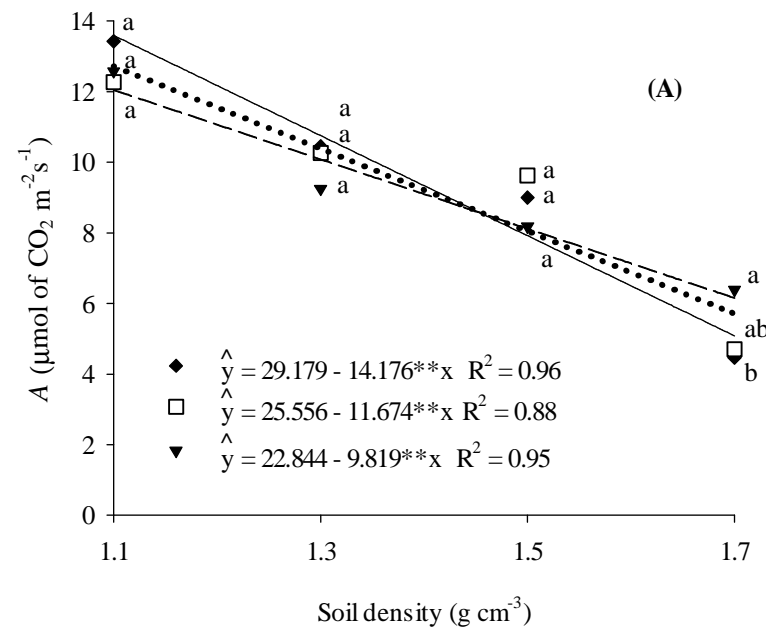

The interaction between lima bean genotypes and soil densities significantly affected the photosynthetic rate $(A)$. The $A$ of the genotypes in compaction levels $1.1,1.3$ and $1.5 \mathrm{~g} \mathrm{~cm}^{-3}$ was similar, but at the most severe compaction level, the $A$ of the genotype Roxinha was higher than that of the Branca-Pequena, without differing from that of the Orelha-de-Vó (Figure 2A). The $A$ of the three genotypes fitted to the linear regression model, with a reduction of 67 (Branca-Pequena), 62 (Orelha-de-Vó) and 51\% (Roxinha) from the lowest to the highest compaction level.

The leaf transpiration $(E)$ of the Orelha-de-Vó in the soil density of $1.5 \mathrm{~g} \mathrm{~cm}^{-3}$ was statistically greater than that of the Branca-Pequena, without differing from that of the Roxinha (Figure 2B). The $E$ of the Roxinha fitted to the linear regression model, with a reduction of $1.56 \mathrm{mmol}$ of $\mathrm{H}_{2} \mathrm{O} \mathrm{m}^{-2} \mathrm{~s}^{-1}$ at each increase in soil density. On the other hand, Branca-Pequena and Orelha-de-Vó fitted to the quadratic model presenting the highest $E$ rates at the soil densities of 1.27 and $1.24 \mathrm{~g} \mathrm{~cm}^{-3}$, respectively.

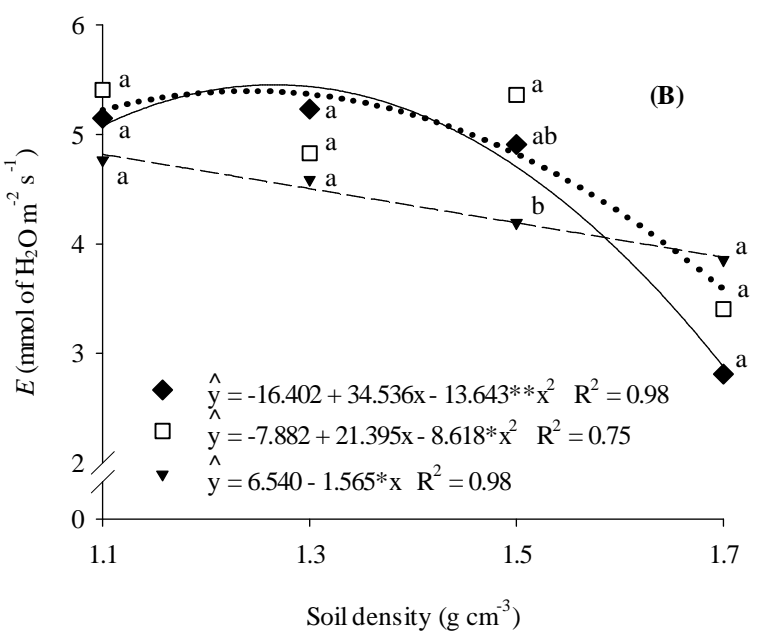

$*=$ significant at 5 probability, and $* *=$ significant at $1 \%$ probability by the $\mathrm{F}$ test in the regression analysis. Means followed by the same letter in the same soil density do not differ statistically by the Tukey's test at $5 \%$ probability.

Figure 2. Photosynthetic rate $(A)(\mathrm{A})$, and leaf transpiration $(E)(\mathrm{B})$ of the lima bean (Phaseolus lunatus L.) genotypes Branca-Pequena $(\bullet)$; Orelha-de-Vó $(\square)$ and Roxinha $(\boldsymbol{\nabla})$, at 38 days after sowing in response to soil compaction levels.

The genotype Roxinha had higher photosynthetic rate in the highest compaction level. Thus, this genotype has potential to be grown in soils that presents some physical impediment to root growth. However, it is necessary to evaluate how much this higher photosynthetic rate affects the plant yield. Reductions in the photosynthetic rate were also observed by $\mathrm{Tu}$ and Tan (1988) in common bean varieties grown in compacted soil $\left(1.6 \mathrm{~g} \mathrm{~cm}^{-3}\right)$, with reductions of up to $46 \%$. Campostrini and Yamanishi (2001), observed reductions in the photosynthetic rates (28 to $51 \%$ ) of papaya genotypes grown in compacted soil (4.12 MPa), and attributed this result to the reduction of stomatal conductance caused by the transport of abscisic acid from the root to the shoot.

Orelha-de-Vó had greater leaf transpiration than Roxinha at the soil density of $1.5 \mathrm{~g} \mathrm{~cm}^{-3}$, which denoted its smaller efficiency in reduce losses of water by transpiration. This difference can be attributed to the different adaptation mechanisms of plants under different stress conditions. An example is the reduction in the hydraulic conductivity of the bean root in response to saline stress (CALVO-POLANCO; SÁNCHEZ-ROMERA; AROCA, 2014). According to Ollas and Dodd (2016), changes in root hydraulic conductivity may affect the water status of the plant to control transpiration. The maximum rates of $E$ was 5.45 (Branca-Pequena) and $5.40 \mathrm{mmol}$ of $\mathrm{H}_{2} \mathrm{O} \mathrm{m}^{-2} \mathrm{~s}^{-1}$ 
(Orelha-de-Vó) at the soil densities of $1.27 \mathrm{~g} \mathrm{~cm}^{-3}$ and $1.24 \mathrm{~g} \mathrm{~cm}^{-3}$, respectively. These results were similar to those found by Ferraz et al. (2012) in common bean ecotypes grown under field conditions in the Semiarid region of Brazil.

The stomatal conductance $\left(g_{s}\right)$ of the genotypes Branca-Pequena and Roxinha fitted to the linear model, with reductions of 0.18 and $0.12 \mathrm{~mol} \mathrm{~m}^{-2} \mathrm{~s}^{-1}$, respectively, at each increase in soil density (Figure 3A). The $g_{s}$ of the genotype Orelha-de-Vó fitted to the quadratic model, with a maximum value of $0.26 \mathrm{~mol} \mathrm{~m}^{-2} \mathrm{~s}^{-1}$ at the estimated soil density of $1.29 \mathrm{~g} \mathrm{~cm}^{-3}$. These results can be attributed to the abscisic acid and the reduction in the hydraulic conductivity of the root caused by deformations under confinement conditions (FIGUEIREDO et al., 2014). According to Comstock (2002), both chemical and hydraulic signaling are important in the stomatal regulation of plants. In addition, these results explain the reduction in the photosynthetic, and transpiration rates, since $g_{s}$ controls the $\mathrm{CO}_{2}$ entry and water exit in the leaf mesophyll (TAIZ; ZEIGER, 2004).

The highest soil compaction levels caused linear increases in the internal carbon concentrations

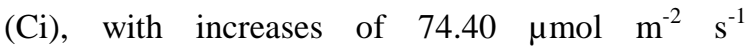
(Branca-Pequena), $\quad 83.39 \mu \mathrm{mol} \quad \mathrm{m}^{-2} \quad \mathrm{~s}^{-1}$ (Orelha-de-Vó), and $53.92 \mu \mathrm{mol} \mathrm{m}^{-2} \mathrm{~s}^{-1}$ (Roxinha) at each increase in soil density (Figure 3B). These results denote that the reduction in the photosynthetic rate is due not only to the stomatal limitation but also to the non-fixation of $\mathrm{CO}_{2}$ in the carboxylation phase. Similar results were found by Dias and Brüggemann (2010), who found no changes in $\mathrm{Ci}$ in common bean plants (Phaseolus vulgaris L.) subjected to water stress, when compared to control. These authors also found a $49 \%$ decrease in the activity of the enzymes 1.5 ribulose bisphosphate carboxylase oxygenase (Rubisco) and Ru5PK in stressed plants, thus limiting assimilation of $\mathrm{CO}_{2}$. This probably occurred in the present study, however these enzymes were not analyzed.
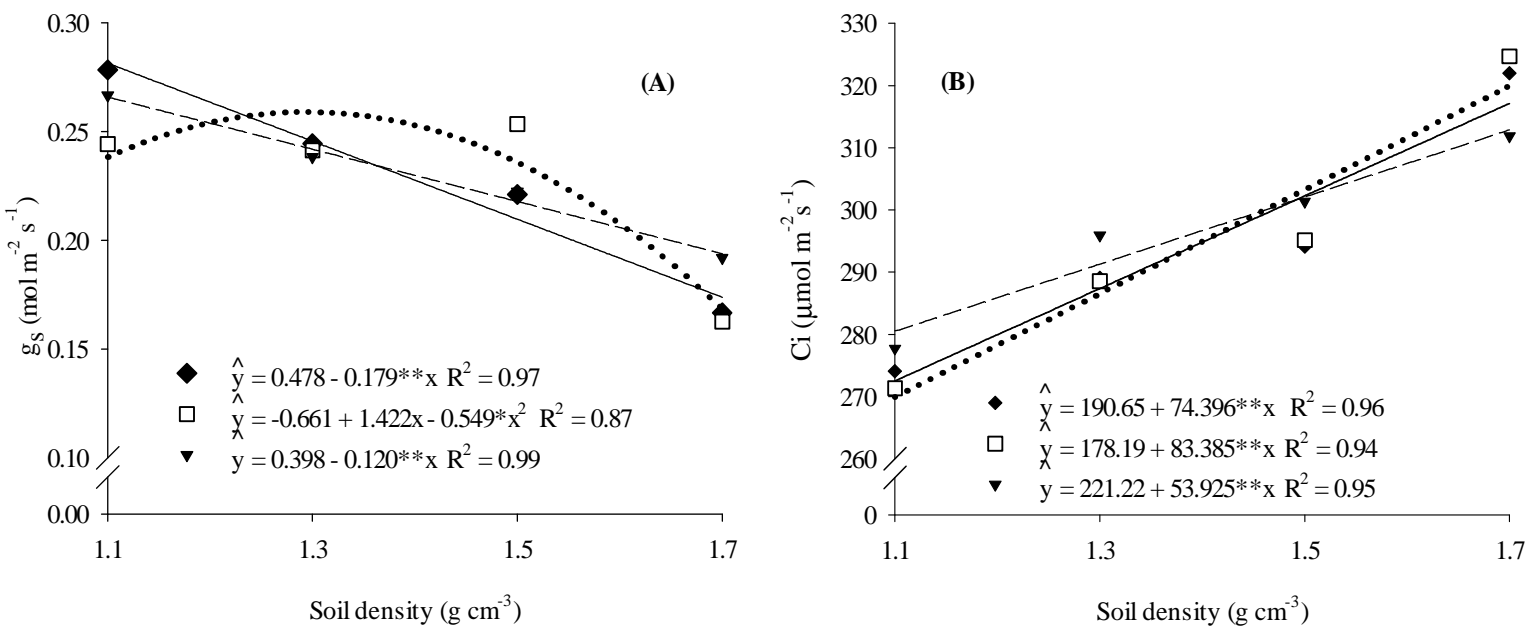

$*=$ significant at 5 probability, and $* *=$ significant at $1 \%$ probability by the $\mathrm{F}$ test in the regression analysis.

Figure 3. Stomatal conductance (gs) (A) and internal $\mathrm{CO}_{2}$ concentration (Ci) (B) of the lima bean (Phaseolus lunatus $\mathrm{L}$.) genotypes Branca-Pequena ( $\bullet)$, Orelha-de-Vó $(\square)$, and Roxinha $(\boldsymbol{\nabla})$, at 38 days after sowing in response to soil compaction levels.

The instantaneous efficiency in water use (WUE), intrinsic water use efficiency (iWUE) and instantaneous carboxylation efficiency (iCE) had linear reductions with increasing soil compaction in all genotypes (Figure 4A, 4B and 4C). The WUE of the genotypes reduced 1.67 (Branca-Pequena), 1.30

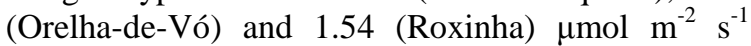
$\left(\mathrm{mmol} \mathrm{H} \mathrm{O} \mathrm{m}^{-2} \mathrm{~s}^{-1}\right)^{-1}$ at each increase in soil density; the iWUE of the genotypes reduced 28.10 (Branca-Pequena), 25.81 (Orelha-de-Vó) and 22.61 (Roxinha) $\mu \mathrm{mol} \mathrm{m} \mathrm{m}^{-2} \mathrm{~s}^{-1}\left(\mathrm{~mol} \mathrm{~m} \mathrm{~m}^{-2} \mathrm{~s}^{-1}\right.$ at each increase in soil density; and the iCE of the genotypes reduced 0.056 (Branca-Pequena), 0.043

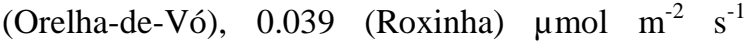
$\left(\mu \mathrm{mol} \mathrm{m} \mathrm{m}^{-2}\right)^{-1}$ at each increase in soil density.

The reductions in the WUE and iWUE were due to the gradual decrease of the $g_{s}$ with increasing soil compaction, without maintenance of the photosynthetic rate. Reductions in $g_{s}$, with negative effects on $A$ and $E$ due to soil compaction have been reported in several crops (GRZESIAK et al., 2013; WANG et al., 2013). The iCE reduced because the photosynthetic rate did not follow the increase of the $\mathrm{Ci}$ generated by the increased compaction levels. According to Machado et al. (2005), photosynthesis, intracellular $\mathrm{CO}_{2}$ concentration, and assimilation of carbon dioxide are connected. 

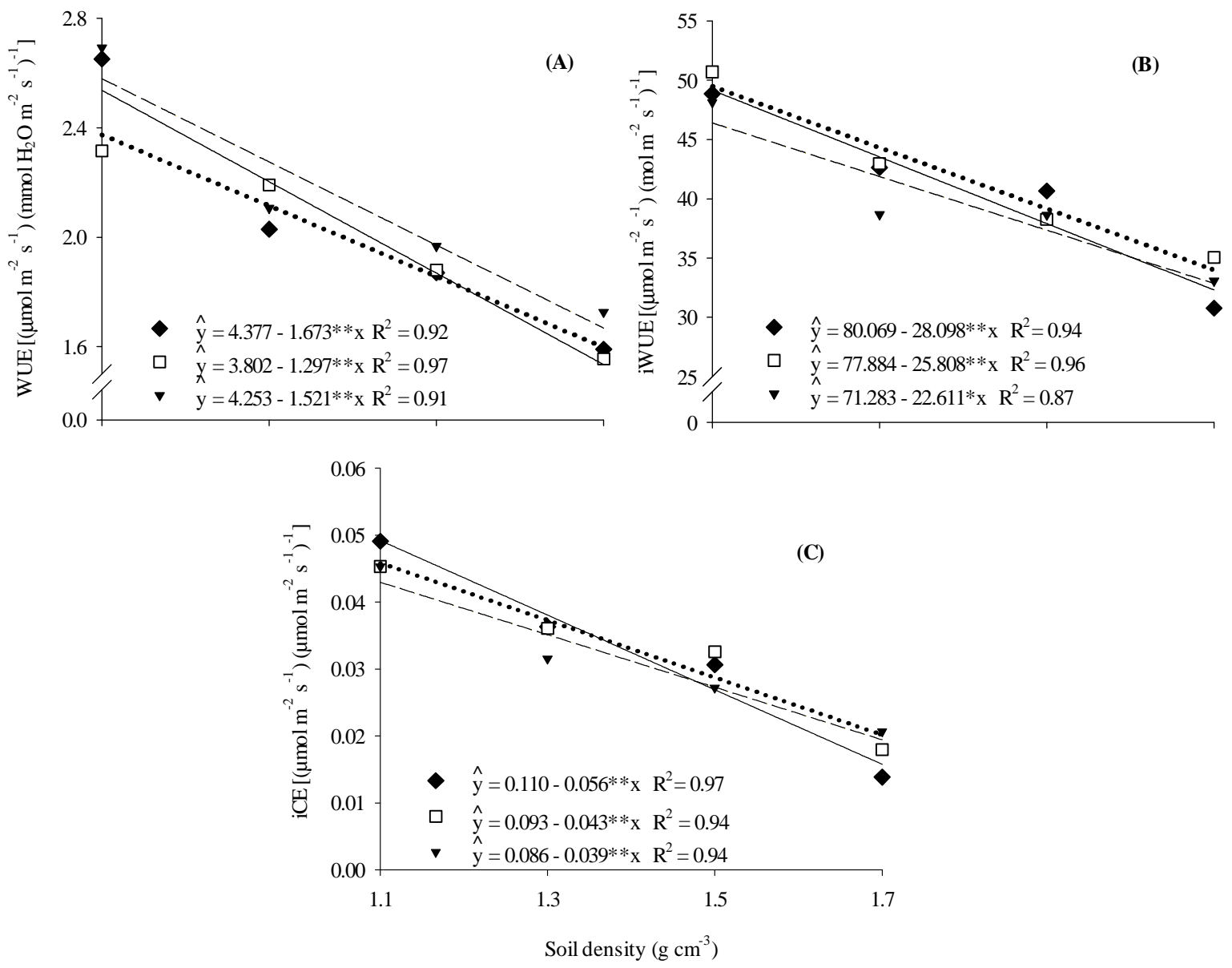

$*=$ significant at 5 probability, and $* *=$ significant at $1 \%$ probability by the $\mathrm{F}$ test in the regression analysis.

Figure 4. Instantaneous water use efficiency (WUE) (A); intrinsic water use efficiency (iWUE) (B), and instantaneous carboxylation efficiency (iCE) (C) of the lima bean (Phaseolus lunatus L.) genotypes Branca-Pequena ( $\bullet$ ); Orelha-de-Vó $(\square)$ and Roxinha $(\boldsymbol{\nabla})$, at 38 days after sowing in response to soil compaction levels.

The initial fluorescence $(F o)$ of the genotype Branca-Pequena at density of $1.5 \mathrm{~g} \mathrm{~cm}^{-3}$ was greater than that of the Orelha-de-Vó, but did not differ from that of the genotype Roxinha (Figure 5A). The Fo was not altered by soil compaction levels, regardless of the genotype. However, the maximum $(\mathrm{Fm})$ and variable $(F v)$ fluorescence, and the quantum efficiency of photosystem II $(F v / F m)$ of the genotype Orelha-de-Vó fitted to the regression models-linear for $\mathrm{F} m$ and $F v$, and quadratic for $F v / F m$ (Figure 5B, 5C and 5D). The $F m$ reduced 43.7, and the $F v$ reduced and 41.0 at each increase in soil density. The genotype Orelha-de-Vó reached the maximum $F v / F m$ of 0.730 in the soil density of $1.29 \mathrm{~g} \mathrm{~cm}^{-3}$.

The increase in Fo represents a decrease in the energy transfer capacity of the antenna to the photosystem II, or destruction of the reaction center of photosystem II (P680) (BAKER; ROSENQVST, 2004; MELO et al., 2010). Thus these results indicate that the genotype Branca-Pequena had its energy transfer capacity compromised at the density level of $1.5 \mathrm{~g} \mathrm{~cm}^{-3}$. The reductions in $F m$ and $F v$ show that the increased soil compaction reduced the maximum capacity of photochemical reactions of the genotype Orelha-de-Vó, and its ability to transfer the energy of the electrons to the production of chemical energy (BAKER, 2008). However, the effect of temperature on the reduction of both variables cannot be ruled out due to its sensitivity to temperature increase, as described by Vieira et al. (2010).

Philip and Azlin (2005) reported that the soil compaction did not alter Fo and Fm in Lagestromia speciosa L., but altered the quantum efficiency of photosystem II $(F v / F m)$. These results are partly similar to those found by Shukor et al. (2015), who evaluated the effect of compaction on the decrease of $F v / F m$ in Azadirachta excelsa, however, unlike Philip and Azlin (2005), these authors also found decreases in $F m$ and $F v$. 

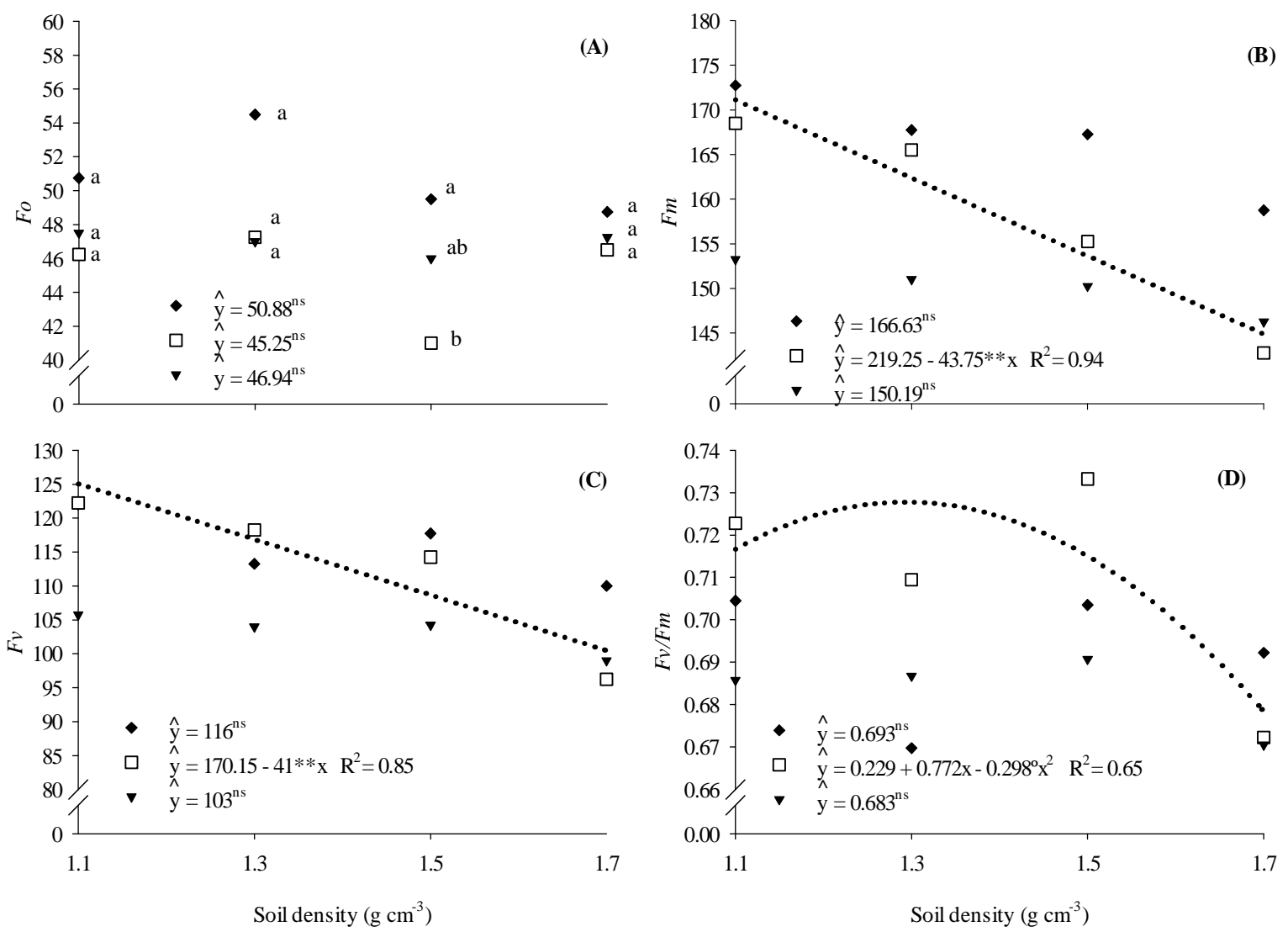

$*_{*}^{*}=$ significant at 1 probability, and ${ }^{\circ}=$ significant at $10 \%$ probability by the $\mathrm{F}$ test in the regression analysis. Means followed by the same letter in the same soil density do not differ statistically by the Tukey's test at $5 \%$ probability.

Figure 5. Initial fluorescence $(F o)(\mathrm{A})$; maximum fluorescence $(F m)(\mathrm{B})$; variable fluorescence $(F v)(\mathrm{C})$ and quantum efficiency of photosystem II $(F v / F m)$ (D) of the lima bean (Phaseolus lunatus L.) genotypes Branca-Pequena ( $)$; Orelha-de-Vó ( $\square$ ) and Roxinha ( $\mathbf{\nabla})$, at 38 days after sowing in response to soil compaction levels.

No significant differences in $F v / F m$ were found between the lima bean genotypes. This indicates that they are genetically very close regarding photochemical activity, as also pointed out by Portes and Magalhães (1993) in common bean genotypes. The genotype Roxinha had the lowest $F v /$ $F m$ at the highest compaction level $\left(1.7 \mathrm{~g} \mathrm{~cm}^{-3}\right)$, however, this not resulted in a lower photosynthetic rate (Figure 2A). This result indicates that a $F v / F m$ below 0.750 do not always represent a lower photosynthetic rate, although, they are correlated (LIMA, 2014).

The genotype Orelha-de-Vó had a $F v / F m$ of 0.730 at the estimated soil density of $1.29 \mathrm{~g} \mathrm{~cm}^{-3}$. This $F v / F m$ was lower than that recommended by Lichtenthaler, Buschmann and Knapp (2005) for non-stressed plants- 0.740 to 0.850 . However, Li et al. (2004) found $F v / F m$ of 0.660 to 0.783 in legumes, which indicates that the optimum $F v / F m$ of 0.750 to 0.850 may not apply to lima bean plants. Grzesiak (2009) observed reductions of 15 and $36 \%$ in $\mathrm{Fv} / \mathrm{Fm}$ in triticale and maize, respectively, grown in compacted soils $\left(1.58 \mathrm{~g} \mathrm{~cm}^{-3}\right)$.

\section{CONCLUSIONS}

The soil compactions decreased stomatal conductance and increased internal $\mathrm{CO}_{2}$ concentration of the lima bean genotypes evaluated. It reduced leaf transpiration and photosynthetic rate by both stomatal and non-stomatal factors.

Regarding the genotypic performance, the genotype Roxinha was more efficient than the genotype Branca-Pequena, considering its photosynthetic rate at the soil density of $1.7 \mathrm{~g} \mathrm{~cm}^{-3}$; and more efficient in reducing water loss by transpiration than the genotype Orelha-de-Vó at the soil density of $1.5 \mathrm{~g} \mathrm{~cm}^{-3}$.

The increase in soil compaction levels did not decrease the photochemical efficiency of the genotypes Branca-Pequena and Roxinha, but decreased the photochemical efficiency of the genotype Orelha-de-Vó, except its initial fluorescence.

Future studies should be carried out to identify more tolerant lima bean genotypes, and which adaptation mechanisms are most used to reduce their physical stress by compaction, 
especially those connected to the hydraulic conductivity of the root system.

\section{REFERENCES}

BAKER, N. R. Chlorophyll fluorescence: A probe of photosynthesis in vivo. Annual Review of Plant Biology, Palo Alto, v. 59, s/n., p. 89-113, 2008.

BAKER, N. R.; ROSENQVST, E. Application of chlorophyll fluorescence can improve crop production strategies: an examination of future possibilities. Journal of Experimental Botany, Oxford, v. 55, n. 403, p. 1607-1621, 2004.

CALVO-POLANCO, M.; SÁNCHEZ-ROMERA, B.; AROCA, R. Mild salt conditions induce different response in root hydraulic conductivity of Phaseolus vulgaris over-time. Plos One, San Francisco, v. 9, n. 3, p. e90631, 2014.

CAMPOSTRINI, E.; YAMANISHI, O. K. Influence of mechanical root restriction on gas-exchange of four papaya genotypes. Brazilian Journal Plant Physiology, Campos dos Goytacazes, v. 13, n. 2, p. 129-138, 2001.

COMSTOCK, J. P. Hydraulic and chemical signalling in the control of stomatal condutance and transpiration. Journal of Experimental Botany, Oxford, v. 53, n. 367, p. 195-200, 2002.

DIAS, M. C.; BRÜGGEMANN, W. Limitations of photosynthesis in Phaseolus vulgaris under drought stress: gas exchange, chlorophyll fluorescence and Calvin cycle enzymes. Photosynthetica, Prague, v. 48, n. 1, p. 96-102, 2010.

EMPRESA BRASILEIRA DE PESQUISA AGROPECUÁRIA - EMBRAPA. Centro Nacional de Pesquisa de Solos. Manual de métodos de análise de solo. 2. ed. Rio de Janeiro, RJ: Embrapa, 2011. $230 \mathrm{p}$.

FERRAZ, R. L. S. et al. Trocas gasosas e eficiência fotossintética em ecótipos de feijoeiro cultivados no semiárido. Pesquisa Agropecuária Tropical, Goiânia, v. 42, n. 2, p. 181-188, 2012.

FERREIRA, D. F. SISVAR: um programa para análises e ensino de estatística. Revista Symposium, Recife, v. 6, p. 36-41, 2008.

FIGUEIREDO, F. A. M. M. A. et al. Condutividade hidráulica de raiz e capacidade fotossintética de mudas clonais de Eucalipto com indução de deformações radiculares. Ciência Florestal, Santa Maria, v. 24, n. 2, p. 277-287, 2014.
GRZESIAK, M. T. Impact of soil compaction on root architecture, leaf water status, gas exchange and growth of maize and triticale seedlings. Plant Root, Toyama, v. 3, s/n., p. 10-16, 2009.

GRZESIAK, S. et al. Changes in root system structure, leaf water potential and gas exchange of maize and triticale seedlings affected by soil compaction. Environmental and Experimental Botany, Oxford, v. 88, s/n., p. 2-10, 2013.

GRZESIAK, M. T. et al. Impact of soil compaction stress combined with drought or waterlogging on physiological and biochemical markers in two maize hybrids. Acta Physiologiae Plantarum, Warszawa, v. 38, n. 109, p. 2-15, 2016.

GUBIANI, P. I.; REICHERT, J. M.; REINERT, D. J. Interação entre disponibilidade de água e compactação do solo no crescimento e na produção de feijoeiro. Revista Brasileira de Ciência do Solo, Viçosa, v. 38, n. 3, p. 765-773, 2014.

HERNANDEZ-RAMIREZ, G. et al. Root responses to alterations in macroporosity and penetrability in a silt loam soil. Soil Science Society of America Journal, Madison, v. 78, n. 4, p. 1392-1403, 2014.

KOZLOWSKI, T. T. Soil compaction and growth of Woody plants. Scandinavian Journal of Forest Research, Oslo, v. 14, n. 6, p. 596-619, 1999.

KUNCORO, P. H. et al. A study on the effect of compaction transport properties of soil gas and water I: Relative gas diffusivity, air permeability, and saturated hydraulic conductivity. Soil \& Tillage Research, Amsterdam, v. 143, s/n., p. 172-179, 2014.

LI, Y. G. et al. Traits of chlorophyll fluorescence in 99 plants species from the sparse-elm grassland in Hunshandak Sandland. Photosynthetica, Prague, v. 42, n. 2, p. 243-249, 2004.

LICHTENTHALER， H. K.; BUSCHMANN， C.; KNAPP, M. How to correctly determine the different chlorophyll fluorescence parameters and the chlorophyll fluorescence decrease ratio $\mathrm{RFd}$ of leaves with the PAM fluorometer. Photosynthetica, Prague, v. 43, n. 3, p. 379-393, 2005.

LIMA, C. L. R. et al. Produtividade de culturas e resistência à penetração de Argissolo Vermelho sob diferentes manejos. Pesquisa Agropecuária Brasileira, Brasília, v. 45, n. 1, p. 89-98, 2010.

LIMA, R. S. N. Irrigação parcial do sistema radicular e déficit de irrigação regulado em mamoeiro (Carica papaya L.): capacidade fotossintética, crescimento e eficiência no uso da 
água. 2014. 129 f. Tese (Doutorado em Produção Vegetal: Área de Concentração em Produção Vegetal) - Universidade Estadual do Norte Fluminense, Rio de Janeiro, 2014.

MACHADO, E. C. et al. Respostas da fotossíntese de três espécies de citros a fatores ambientais. Pesquisa Agropecuária Brasileira, Brasília, v. 40, n. 12 , p. 1161-1170, 2005.

MELO, A. S. et al. Crescimento vegetativo, resistência estomática, eficiência fotossintética e rendimento do fruto da melancieira em diferentes níveis de água. Acta Scientiarum Agronomy, Maringá, v. 32, n. 1, p. 73-79, 2010.

MOURA, P. M. et al. Efeito da compactação em dois solos de classes texturais diferentes na cultura do rabanete. Revista Caatinga, Mossoró, v. 21, n. 5, p. 107-112, 2008.

NAWAZ, M. F.; BOURRIÉ, G.; TROLARD, F. Soil compaction impact and modelling. A review. Agronomy for Sustainable Development, Paris, v. 33, n. 2, p. 291-309, 2013.

OLLAS, C.; DODD, I. C. Physiological impacts of ABA-JA interactions under water-limitation. Plant Molecular Biology, Zurich, v. 91, n. 6, p. 641-640, 2016.

PEGADO, C. M. A. et al. Decomposição superficial e sub-superficial de folhas de fava (Phaseolus lunatus L.) na região do Brejo da Paraíba, Brasil. Revista Caatinga, Mossoró, v. 21, n. 1, p. 218-223, 2008.

PHILIP, E.; AZLIN, Y. N. Measurement of soil compaction tolerance of Lagestromia speciosa (L.) Pers. using chlorophyll fluorescence. Urban Forestry \& Urban Greening, Jena, v. 3, n. 3, p. 203 $-208,2005$

PORTES, T. A.; MAGAlHÃES, A. C. N. Análise comparativa de diferentes genótipos de feijão através da medição da fluorescência da clorofila $a$ e do balanço de $\mathrm{O}_{2}$. Revista Brasileira de Fisiologia Vegetal, Londrina, v. 5, n. 1, p. 17-23, 1993.

SANTOS, M. G. et al. Photosynthetic parameter sand leaf water potential of five common bean genotypes under mild water déficit. Biologia Plantarum, Prague, v. 53, n. 2, p. 229-236, 2009.

SHUKOR, N. N. et al. Effects of soil compaction on growth and physiological characteristics of Azadirachta excelsa seedlings. American Journal of Plant Physiology, New York, v. 10, n. 1, p. 2542,2015
SILVA, G. J.; MAIA, J. C. S.; BIANCHINI, A. Crescimento da parte aérea de plantas cultivadas em vaso, submetidas à irrigação subsuperficial e a diferentes graus de compactação de um Latossolo Vermelho-Escuro distrófico. Revista Brasileira de Ciência do Solo, Viçosa, v. 30, n. 1, p. 31-40, 2006.

SILVEIRA, D. C. et al. Relação umidade versus resistência à penetração para um Argissolo Amarelo distrocoeso no recôncavo da Bahia. Revista Brasileira de Ciência do Solo, Viçosa, v. 34, n. 3, p. 659-667, 2010.

STONE, L. F.; GUIMARÃES, C. M.; MOREIRA, J. A. A. Compactação do solo na cultura do feijoeiro. I: efeitos nas propriedades físico-hídricas do solo. Revista Brasileira de Engenharia Agrícola e Ambiental, Campina Grande, v. 6, n. 2, p. 207-212, 2002.

SUZUKI, L. E. A. S. et al. Grau de compactação, propriedades físicas e rendimento de culturas em Latossolo e Argissolo. Pesquisa Agropecuária Brasileira, Brasília, v. 42, n. 8, p. 1159-1167, 2007.

TAIZ, L.; ZEIGER, E. Fisiologia vegetal. 3. ed. Porto Alegre, RS: Artmed, 2004. 719 p.

TU, J. C.; TAN, C. S. Soil compaction effect on photosynthesis, root rot severity, and growth of white beans. Canadian Journal of Soil Science, Ottawa, v. 68, n. 2, p. 455-459, 1988.

VALADÃO, F. C. A. et al. Adubação fosfatada e compactação do solo: sistema radicular da soja e do milho e atributos físicos do solo. Revista Brasileira de Ciência do Solo, Viçosa, v. 39, n. 3, p. 243-255, 2015.

VIEIRA, D. A. P. et al. Fluorescência e teores de clorofilas em abacaxizeiro cv. pérola submetido a diferentes concentrações de sulfato de amônio. Revista Brasileira de Fruticultura, Jaboticabal, v. 32 , n. 2 , p. $360-368,2010$

WANG, D. et al. Effects of soil compaction stress on carbohydrate metabolismo of cucumber. Journal Plant Nutrition and Fertilizer Science, Pequim, v. 19, n. 1, p. 159-175, 2013 